\title{
Transforming livestock productivity through watershed interventions: A case study of Parasai-Sindh watershed in Bundelkhand region of Central India
}

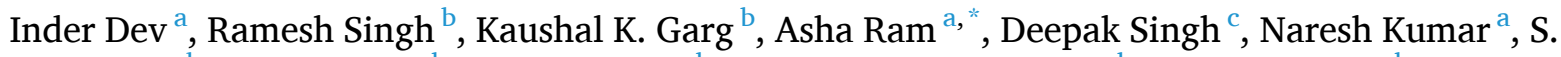 \\ K. Dhyani ${ }^{\mathrm{d}}$, Anand Singh ${ }^{\mathrm{b}}$, K.H. Anantha ${ }^{\mathrm{b}}$, VenkataRadha Akuraju ${ }^{\mathrm{b}}$, Sreenath Dixit ${ }^{\mathrm{b}}$, R. \\ K. Tewari ${ }^{\text {a }}$, R.P. Dwivedi ${ }^{\text {a }}$, A. Arunachalam ${ }^{\text {a }}$ \\ ${ }^{a}$ ICAR-Central Agroforestry Research Institute, Jhansi 284003, Uttar Pradesh, India \\ b International Crops Research Institute for the Semi-Arid Tropics (ICRISAT), Patancheru, Hyderabad 502324, Telangana, India \\ ${ }^{c}$ ICAR-Indian Agricultural Statistics Research Institute, New Delhi 110012, India \\ ${ }^{\mathrm{d}}$ ICRAF South Asia Office, New Delhi 110012, India
}

\section{H I G H L I G H T S}

- Poor crop and livestock productivity is a critical challenge in drylands and watershed interventions could help build resilience to this

- Interlinkages among land-water-croplivestock sectors and their sustainability have been studied

- Watershed based interventions enhanced groundwater availability, which reduced risk of crop failure, increased crop intensification and productivity

- Forage availability has improved from deficit to surplus status due to watershed interventions despite significant increase in livestock population

- Integrating land-water-crop-livestock interventions in watersheds can provide opportunities to improve rural livelihoods in drylands

\section{A R T I C L E I N F O}

Editor: Jagadish Timsina

\section{Keywords:}

Forage deficit

Natural resource management

Livelihood improvement
G R A P H I C A L A B S T A R C T



\section{A B S T R A C T}

CONTEXT: Global experiences reveal the positive impact of watershed-based interventions in improving livelihoods and environmental security. In the drylands, increasing forage resources and improving livestock productivity is a critical challenge.

OBJECTIVES: The overarching aim of this paper is to analyse the impact of watershed-based interventions on livestock population, productivity, fodder resources, and biomass availability. The paper describes the interrelationship between land, water, crop, and livestock and how the gap in forage deficit can be bridged through a range of watershed interventions.

\footnotetext{
* Corresponding author.

E-mail address: Asha.Ram@icar.gov.in (A. Ram).
} 
Drylands

Smallholder farmers
METHODS: The study was undertaken in the Parasai-Sindh watershed of Central India between 2011 and 2016 . A 300-year-old defunct haveli (a traditional rainwater harvesting structure) was renovated and nine check dams along the drainage line were constructed. Nearly 25,000 running-meters of field bunds were constructed. Large fields (2-3 ha) were divided into relatively smaller plots (0.3-0.5 ha) to reduce runoff velocity. The impact of watershed interventions on water availability, livestock productivity, forage yield, and income was studied through hydrological monitoring, primary household survey and principal component analysis (PCA) biplot and hierarchical clustering.

RESULTS AND CONCLUSIONS: The watershed interventions enhanced groundwater availability leading to greater fodder availability, $22 \%$ increase in livestock population (ACU) and a $120 \%$ increase in milk production over a period of five years. The bovine population recorded a surge of 193\% (cattle) and 32\% (buffalo) over this period. Mean dry matter (DM, fodder) availability also increased from 10 t/household/year to 16.7 t/household/ year owing to improved water availability. Groundnut (rainy season) and wheat (post rainy season) contributed significantly as forage resources. There was an annual forage demand of $5560 \mathrm{t} \mathrm{DM}$ for a livestock population of 2175 ACU in 2011 and of 6770 t DM for a livestock population of 2650 ACU in 2016. Annual forage biomass availability was estimated at 4219 t DM in 2011 and 6977 t DM in 2016. There was a deficit of 1341 t DM (24\%) in 2011 which turned into a 3\% surplus of 210 t DM in 2016 through watershed-based interventions. With increased cropping intensity and milk production, average annual household income increased from US\$1325 to US\$ 2430 over the five-year period.

SIGNIFICANCE: This case study clearly illustrates the impact of watershed-based interventions on livestock population, productivity, forage resources, and biomass availability to bridge the gap in forage deficit. Its findings serve as a guide to widely scale up watershed-based interventions for improved water and biomass availability, and livestock productivity in semi-arid and dryland regions.

\section{Introduction}

Drylands face a number of challenges such as water scarcity, land degradation, poor agriculture and livestock productivity, and vulnerability to climate aberrations (Schlaepfer et al., 2017; Singh et al., 2019). Agriculture and allied sectors are the major sources of income for more than $60 \%$ of the rural households residing in these areas (FAO, 2015; 2013). While the drylands are also beset with poverty and malnutrition largely due to fragmented land holdings, poor production and frequent crop failure (Bharucha, 2019; Chikwanha et al., 2021), they hold huge potential to bridge yield gaps through natural resource management interventions, since current resource use efficiency is much less than the achievable potential (Anantha et al., 2021a; Wani et al., 2017). Studies indicate that the conversion of degraded pasture lands into productive grasslands is not only helping meet fodder demand but also supporting other ecosystem services (Anantha et al., 2021b; Garg et al., 2021b). A meta-analysis of 86 studies revealed a higher net accumulation of soil carbon, more microbial activity, and other benefits when grasslands are converted into the silvopastoral system (Feliciano et al., 2018). Increasing livestock population compounded by shrinking common property lands has led to a shortage of fodder in India. This situation has been further aggravated by the introduction of genetically improved cattle that require more feed than the indigenous ones (Kumar and Singh, 2015). The demand-supply gap in fodder is widening primarily due to water scarcity, decreasing area under fodder cultivation, crop residue burning, and stagnant crop production (National Livestock Policy, 2013).

The livestock sector plays an important role in the drylands in terms of ensuring food security and a source of income. It supports the livelihoods of about $69 \%$ of farming households in India (National Livestock Policy, 2013). India has the largest livestock population in the world (535.78 million) with $35.9 \%$ cattle, $27.8 \%$ goats, $20.5 \%$ buffaloes, $14 \%$ sheep and $1.7 \%$ pigs (20th Livestock census, 2019). The sector also contributes $4.1 \%$ to the country's Gross Domestic Product (GDP), $25.6 \%$ to the agricultural GDP, and employs $8.8 \%$ of the population (Reddy et al., 2017; Mekonnen et al., 2021; Planning Commission, 2011; Sekaran et al., 2021). Its contribution to the agricultural GDP has been higher than that of the crop sector in the past decades because of the increased demand for animal-based products (Ali, 2007; Enahoro et al., 2018; Komarek et al., 2021). In the coming decades, consistent growth of the livestock sector could turn it into the engine for agricultural growth (Suthar et al., 2019), export earnings (Birthal et al., 2006), and as a source of livelihood for rural households (Ruggia et al., 2021; Varijakshapanicker et al., 2019). India is the largest milk producer globally. However, its very low productivity remains a critical challenge in a country with existing fodder and feed issues. India faces a net deficit of $36 \%$ green fodder, $11 \%$ dry fodder, and $44 \%$ concentrate feed ingredients (IGFRI, 2015). To sustain its livestock sector, the supply of green forage needs to grow at $1.7 \%$ annually (IGFRI, 2015).

Realizing these challenges, watershed development programs in India have focused on landscape-based interventions to holistically address land-water-crop-tree-livestock components. In India, the watershed program has been evolving over a period of time (Garg et al., 2021a). Between 1970 and 1980, the focus was on landscape protection and erosion control through field bunding as an in situ soil conservation measure. While this had its benefits, its full potential were not realised as the approach followed was contractual and community participation, which is the crux of sustainability in natural resource management (NRM) interventions, was lacking (Garg et al., 2012, 2020b; Karlberg et al., 2015). The approach was modified in subsequent decades (1990s) by adding a water conservation component, wherein rainwater harvesting structures were included; these generated benefits in terms of increased groundwater recharge and crop intensification. In the late 1990s, a new productivity enhancement approach was introduced along with livestock promotion to improve the productivity of small and marginal farms. This was crucial to address food security and crop intensification (Garg et al., 2020a).

Global experiences have demonstrated the positive impact of watershed-based natural resource management interventions on improving livelihood and environmental security (Garg et al., 2020b; Hope, 2007; Kerr, 2002). However, an understanding of their impact on the water-agriculture-livestock dynamics is limited (Arya et al., 2011; Descheemaeker et al., 2010). This study investigated the impact of watershed interventions on livestock population and productivity, forage resources and biomass availability in one of the degraded ecologies (Bundelkhand region) in central India. The objectives of the study were to explore the interaction between water-crop-livestock sectors and to test how the interventions can bridge the gap in forage availability in this fragile ecoregion. 


\section{Materials and methods}

\subsection{Study area}

\subsubsection{Bundelkhand region of central India}

Bundelkhand region in central India is a hotspot of poverty, malnutrition, and poor agriculture and livestock productivity. The region is characterised by a harsh climate, with temperatures reaching $47^{\circ} \mathrm{C}$ in May and June and annual rainfall ranging from 600 to $800 \mathrm{~mm}$, with large temporal and spatial variability. Shallow unconfined groundwater aquifers are the primary source of freshwater for domestic and agricultural uses. However, they get depleted during the postmonsoon period and summer. Unreliable groundwater availability in the region has led to higher risk of crop failure (Dev et al., 2020; Garg et al., 2020b; Gupta et al., 2014).

About $80 \%$ of the population in the region is dependent on the agriculture and livestock sectors. Immense biotic pressure on forests, community lands, and declining vegetation cover have resulted in a scarcity of fodder and fuelwood in the region, adversely affecting livelihood security (Dev et al., 2018, 2016). The landless and small farmers maintain at least one cow/buffalo or a few goats as an asset for assured income. Fodder shortage during the lean period compels them to leave their cattle free to survive (Anna Pratha in local parlance). Between April and October, thousands of domestic animals are released to graze openly before the sowing of the rabi season (post-rainy) crop. Every year, this practice reportedly destroys almost $25-35 \%$ of the produce from the

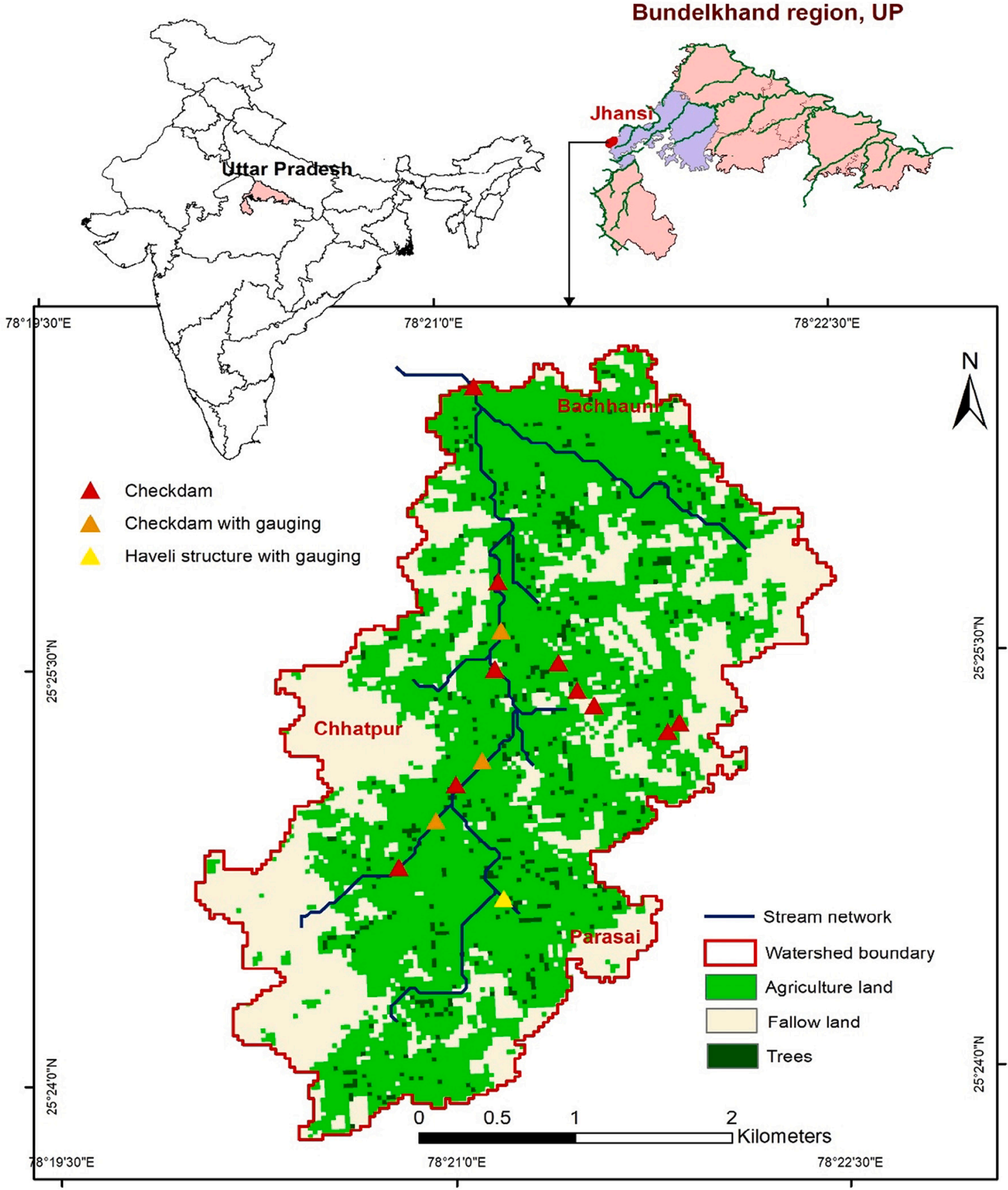

Fig. 1. Location of the Parasai-Sindh watershed, Bundelkhand region, Central India, the major land uses in it in 2011 and the location of ex-situ rainwater harvesting interventions on different ephemeral streams. 
kharif (rainy season) crop (Saran et al., 2000). Therefore, to control stray cattle, initiatives involving fodder production through crop intensification and diversification are considered effective strategies that can go hand in hand with breed improvement. Although farmers feed their livestock green forage during the monsoon season, the dependence on tree leaves during the lean period is predominant (Rathod and Dixit, 2020). Hence the current fodder deficit needs to be met by either increasing productivity, utilizing untapped feed resources including tree fodder, increasing grazing area or through imports.

\subsubsection{Experimental site - Parasai-Sindh watershed}

The study was conducted at Parasai-Sindh watershed $\left(24^{\circ} 11^{\prime}\right.$ and $25^{\circ} 57^{\prime} \mathrm{N}$, latitude and $78^{\circ} 10^{\prime}$ and $79^{\circ} 25^{\prime} \mathrm{E}$ longitude) in Babina block of Jhansi district in Bundelkhand region of central India. The watershed comprises the three villages of Parasai, Chhatpur, and Bachhauni (Fig. 1) covering 1250 ha. The land use and demographic details of the watershed area are presented in Table 1. ICAR-Central Agroforestry Research Institute (CAFRI) and the International Crops Research Institute for the Semi-Arid Tropics (ICRISAT) adopted the watershed in order to transform rural livelihoods by improving water availability, crop, and livestock productivity through a range of soil and water conservation measures, and by introducing improved practices in the crop-treelivestock agroforestry system. This work was part of a larger project of ICAR-CAFRI, Jhansi in collaboration with ICRISAT, Hyderabad, India in 2011. The Parasai-Sindh watershed had 417 households -18 households were landless, 82 were marginal ( $<1$ ha), 146 were small (1-2 ha), 116 were semi-medium (2-4 ha), 50 were medium (4-10 ha) and 5 were large ( $>10$ ha) (Table 1 ). Their main occupation was agriculture and livestock rearing. While large farmers were generating $80 \%$ of their income from agriculture and $20 \%$ from milk production, small and marginal farmers were generating income in equal proportion from both sectors. Groundnut, black gram and sesame (kharif season) and wheat, mustard and chickpea (rabi season) were the preferred crops in the watershed area in 2011. Farmers in these villages are dependent either on rainfed agriculture or shallow dug wells.

The region receives $750 \mathrm{~mm}$ of mean annual rainfall with $85 \%$ of the rains occurring from July to September. The region has had frequent dry spells and drought years ( 3 out of 5 years) which have had an adverse impact on the regional water balance (Singh et al., 2014) especially in

Table 1

Land use pattern and demographic details of the treated Parasai-Sindh watershed.

\begin{tabular}{|c|c|}
\hline Parameters & Treated watershed \\
\hline Villages & Parasai, Chhatpur Bachhauni \\
\hline Area (ha) & 1250 \\
\hline Altitude (masl) & $270-315$ \\
\hline \multicolumn{2}{|l|}{ Land use (ha) in 2011} \\
\hline Agriculture & $1105(88.5 \%)$ \\
\hline Degraded forest & $6(0.5 \%)$ \\
\hline Wasteland (Scrubland) & $66(5 \%)$ \\
\hline Others & $73(6 \%)$ \\
\hline \multicolumn{2}{|l|}{ Demography (based on 2011 census) } \\
\hline Population below 18 years of age (\%) & 52 \\
\hline Literacy (\%) & 56 \\
\hline Number of households & 417 \\
\hline Number of dairy cattle & 2558 \\
\hline Average holdings (ha/household) & 3.12 \\
\hline Number of dug wells & 388 \\
\hline \multicolumn{2}{|c|}{ Landholding (based on 2016 household survey) } \\
\hline Marginal (< 1 ha) & $82(20 \%)$ \\
\hline Small (1-2 ha) & $146(35 \%)$ \\
\hline Semi-medium (2-4 ha) & $116(28 \%)$ \\
\hline Medium (4-10 ha) & $50(12 \%)$ \\
\hline Large (> 10 ha) & $5(1 \%)$ \\
\hline Landless & $18(4 \%)$ \\
\hline
\end{tabular}

Parentheses indicates per cent value of respective parameter. terms of limited groundwater availability. This critical situation has forced communities in the study villages to migrate in search of livelihoods. Livestock, particularly cattle, were usually abandoned due to a shortage of water and fodder during lean periods.

\subsection{Watershed-based interventions}

\subsubsection{Construction of decentralized rainwater harvesting structures}

To improve surface and groundwater availability, the watershed was treated with a range of in-situ and ex-situ rainwater harvesting interventions. In-situ interventions such as the construction of earthen field bunds (0.8-1.5 $\mathrm{m}^{2}$ cross section) and field drainage structures on 203 ha was done on the most upland site of the watershed. Large fields of $2-3$ ha were divided into relatively smaller plots of $0.3-0.5$ ha to reduce runoff velocity, while harvesting a fraction of runoff against the field bunds and stone masonry drainage structures were constructed for the safe disposal of excess runoff.

Ex-situ interventions such as building check dams (1000-10,000 $\mathrm{m}^{3}$ capacity), renovating traditional rainwater harvesting structures (with a storage capacity of $70,000 \mathrm{~m}^{3}$ ), community ponds, and farm ponds were done between 2012 and 2015 following the 'ridge-to-valley' approach (Garg et al., 2021a). The check dams were located at the ephemeral stream (5-10 m wide) network. A 300-year-old defunct haveli located upstream of the watershed with a catchment area of 80 ha was rejuvenated by constructing a core wall and masonry outlet. The total storage capacity created through these ex-situ interventions in the watershed was about $100,000 \mathrm{~m}^{3}$.

To understand the impact of rainwater harvesting interventions on groundwater level, all the 388 dug wells (3-5 $\mathrm{m}$ in diameter and 7-15 $\mathrm{m}$ deep) were monitored every month between 2011 and 2016 using a water level indicator. In addition, rainfall was monitored daily.

\subsection{Sampling procedure and data collection}

Multistage surveys were undertaken by covering all 417 households through structured questionnaire in 2011 (baseline survey during prewatershed intervention phase) and 2016 (post-watershed intervention phase) to ascertain land use pattern, livestock population, forage availability, and milk production (Table 1). Households in each village were categorized based on land size (marginal $\leq 1$ ha, small $=1-2$ ha, semi-medium $=2-4$ ha, medium $=4-10$ ha, large $\geq 10$ ha and the landless). Out of 417 households, 384 (92\%) were male headed and rest 33 were female headed. Post graduate field staff were engaged to undertake household survey and questionnaire were filled only by interacting with the head of the households. In addition, six focused group (FGD) discussion were organized (2 FGD in each village) to realize various challenges/status in the watershed during pre and post interventions.

\subsection{Livestock (adult cattle unit) and fodder requirement}

The livestock population in pre- and post-watershed intervention periods was converted into adult cattle units (ACU) using the standard conversion factor (Dev et al., 2006; Ramchandra et al., 2007; Tyagi and Shankar, 1995) (Table 2) applied based on species, age, and the sex of the animal, using Eq. 1.

One ACU $=\frac{\text { Animal weight }(\mathrm{kg}) \times \text { No.of livestock }}{350}$

Fodder requirement for cattle, buffaloes, sheep, and goats were calculated by taking into consideration a $2 \%$ dry matter (DM) intake per day for every ACU (7 kg DM for 1 ACU of $350 \mathrm{~kg}$ body weight) which is in accordance with available literature (GOI, 2002; Ramchandra et al., 2007; Tanwar and Verma, 2017). The gap between the requirement for and availability of fodder was computed using Eq. 2: 
Table 2

Animal weight and conversion factor used to calculate the adult cattle units (ACUs).

\begin{tabular}{clll}
\hline Species & Age & $\begin{array}{l}\text { Average animal weight } \\
(\mathrm{kg})\end{array}$ & $\begin{array}{l}\text { Conversion } \\
\text { factor }\end{array}$ \\
\hline $\begin{array}{c}\text { Bovine } \\
\text { Cattle }\end{array}$ & Adult (2.5 years) & 350 & \\
& $\begin{array}{l}\text { Young }(<2.5 \\
\text { year) }\end{array}$ & 200 & 1.00 \\
& Adult (2.5 years) & 350 & 0.57 \\
Oxen & Young ( $<2.5$ & 200 & 1.00 \\
& year) & & 0.57 \\
Buffalo & Adult (2.5 years) & 400 & 1.14 \\
& Young (<2.5 & 250 & 0.71 \\
& year) & & \\
Ovine & Adult $(2.5$ years $)$ & 70 & 0.20 \\
Sheep/ & Young $(<2.5$ & 35 & 0.10 \\
goat & year $)$ & & \\
& &
\end{tabular}

Authors' estimates.

Gap percentage $=\frac{\text { Requirement of fodder }- \text { Availability of fodder }}{\text { Requirement of fodder }} \times 100$

\subsection{Estimating forage resources and biomass availability}

Data on forage resources and its production in the watershed were collected through field observations, structured interviews of all households and through focus group discussions (FGDs) to assess pre(2011) and post-intervention (2016) scenarios. The three major sources of fodder supply - crop residues, cultivated fodder from arable land (irrigated and rainfed), and fodder from common property resources (forests, permanent pastures, grazing lands, etc.) - were converted to dry matter to estimate fodder availability. About $50 \%$ of the reported degraded forest and wasteland was considered as available to harvest herbage (Dev et al., 2006; Tyagi and Shankar, 1995). About 2.7\% of the total agricultural land (1105 ha) was available for forage crop cultivation. Similarly, contributions from other land sources such as degraded forest and scrubland were estimated at 50\%. Part of the residues obtained from various crops during kharif and rabi that were fed to livestock were included in the estimation, except for sesame (kharif) and mustard (rabi).

\subsection{Area under bunds, drainage network and other sources of forage availability}

Earthen bunds were the preferred sites for growing grasses. Table 3 presents the area available for forage production in the watershed area. In general, farmers grew forage crops on both sides of the slopes of the earthen bunds. During the pre-intervention phase, the average cross section of the earthen bund was only $0.09 \mathrm{~m}^{2}$. The average top width, bottom width, and height were $0.4 \mathrm{~m}, 0.75 \mathrm{~m}$, and $0.15 \mathrm{~m}$, respectively. The total length of the earthen bund was $350 \mathrm{~m} / \mathrm{ha}$. Accordingly, the total area available for forage cultivation was 18 ha in the entire watershed area of 1250 ha. The farmers also grew forage on both banks (12.6 km-long strip with an average width of $0.8 \mathrm{~m}$ ) of drainage networks (these include stream channels that drain towards the reference point). The net area available for grass cultivation along the drainage network was 2.0 ha.

In pursuing the watershed interventions, the cross section of the earthen field bunds was kept in the range of $0.8 \mathrm{~m}^{2}$ to $1.5 \mathrm{~m}^{2}$ (average of $0.87 \mathrm{~m}^{2}$ ). Earthen bunding of various cross-sections were laid on 102 ha. The average top width, bottom width, and height were $0.5 \mathrm{~m}, 2.3 \mathrm{~m}$, and $0.62 \mathrm{~m}$, respectively. Witnessing the benefits and enhanced water availability, the farmers themselves did the bunding later on an additional 203 ha. This increased the forage cultivation area by up to 42.6 ha. Further, the nallah deepening increased the width of the strip from $0.8 \mathrm{~m}$ to $1.3 \mathrm{~m}$. Hence the total area under forage cultivation on drainage channels was 3.28 ha after the project interventions (Table 3).

Dry fodder availability from different crops, wastelands, fallow

Table 3

Crop area, average crop yield, harvest index and average forage/residue production in Parasai-Sindh watershed.

\begin{tabular}{|c|c|c|c|c|c|}
\hline & \multicolumn{2}{|l|}{ Area (ha) } & \multicolumn{2}{|c|}{ Average crop/forage yield (t/ha) } & \multirow[t]{2}{*}{ Harvest index } \\
\hline & Pre-intervention & Post-intervention & Pre-intervention & Post-intervention & \\
\hline \multicolumn{6}{|l|}{ Kharif season } \\
\hline Groundnut & 692 & 883 & 1.111 & 1.059 & 0.39 \\
\hline Black gram & 117 & 75 & 0.180 & 0.187 & 0.31 \\
\hline Green gram & 47 & 18 & 0.190 & 0.242 & 0.33 \\
\hline Sesame ${ }^{*}$ & - & 54 & - & 0.595 & 0.33 \\
\hline Kharif fodder ${ }^{* *}$ & 17 & 25 & 20.00 & 30.00 & - \\
\hline Kharif fallow ${ }^{* * *}$ & 142 & 50 & 2.00 & 1.75 & - \\
\hline Sub-total & 1015 & 1105 & & & \\
\hline \multicolumn{6}{|l|}{ Rabi season } \\
\hline Wheat & 583 & 975 & 1.677 & 2.376 & 0.37 \\
\hline Chickpea & 83 & 25 & 0.773 & 0.762 & 0.26 \\
\hline Barley & 30 & 50 & 1.422 & 2.235 & 0.40 \\
\hline Mustard* & - & 23 & - & 1.095 & 0.22 \\
\hline Lentil ${ }^{*}$ & - & 15 & - & 0.205 & 0.23 \\
\hline Rabi fallow ${ }^{* *}$ & 292 & 17 & 1.00 & 1.25 & - \\
\hline Sub-total & 988 & 1105 & & & \\
\hline \multicolumn{6}{|l|}{ Others } \\
\hline Area under bunds ${ }^{* *}$ & 17.83 & 42.6 & 1.0 & 1.25 & - \\
\hline Degraded forest ${ }^{* *}$ & 3.00 & 3.00 & 1.0 & 1.0 & - \\
\hline Wasteland (scrubland) ${ }^{* * *}$ & 33.00 & 33.00 & 1.0 & 1.0 & - \\
\hline Drainage channels ${ }^{* *}$ & 2.01 & 3.28 & 2.0 & 3.0 & - \\
\hline Sub-total & 54.87 & 82.16 & & & - \\
\hline Total agricultural land & 1105 & 1105 & & & \\
\hline Total geographical area ${ }^{* * *}$ & 1250 & 1250 & & & \\
\hline
\end{tabular}

* Residue not fed to animals. This was not considered in calculating forage production.

** Forage yield (t/ha),

*** Total geographical area of the watershed included total agricultural land (1105 ha); drainage network (44 ha); degraded forest (6 ha); wasteland ( 66 ha); and road and habitation (29 ha). 
lands, drainage channels, bunds and trees were assessed based on actual field observations and using the Harvest Index (Table 3). Dry matter in dry fodder and concentrate were estimated as per Dev et al. (2016) and Ranjhan et al. (1999).

\subsection{Impact analysis}

The impact of watershed interventions on the bovine population, milk production, and availability of forage resources were calculated using Eqs. 3-5:
2003). According to Yan and Kang (2003), the discriminating ability of test parameters is measured by the length of parameter vectors which is approximate to the standard deviation within each parameter. The longer the parameter vector, the higher are the discriminative abilities. Yan and Kang (2003) proposed the use of biplots in which the representativeness of any parameter can be determined by the proximate angle with the average environment coordinate (AEC). The smaller the angle between AEC and the parameter vector, greater is the representativeness of the tested parameter. The GGE biplot is based on the G + GE tester-centered table without scaling which defines an ideal test environment generally located at the center of the concentric circles

Impact $(\%$ increase in bovine population $)=\frac{\text { Difference in bovine population between } 2016 \text { and } 2011}{\text { Bovine population in } 2011} \times 100$

Impact $(\%$ increase in milk production $)=\frac{\text { Difference in milk production between } 2016 \text { and } 2011}{\text { Milk production in } 2011} \times 100$

Impact $(\%$ increase in forage resources $)=\frac{\text { Difference in forage resources between } 2016 \text { and } 2011}{\text { Forage resources in } 2011} \times 100$

Data on the cultivated area in individual fields in both kharif and rabi seasons were recorded to capture changes in the cropping pattern and crop intensification due to watershed interventions. Details on crop yields and cost of cultivation were also collected for groundnut, black gram, green gram, sesame, and fodder in the kharif season and wheat, chickpea, mustard, and barley in the rabi season during 2011 and 2016. This data was used to estimate total agricultural production by different categories of farmers. Total net income from kharif and rabi was estimated taking into account total yield, market price, and cost of cultivation. Net income from milk production was similarly estimated from individual households.

\subsection{Data analysis and statistical methods}

The impact of watershed interventions on livestock, fodder resources, and biomass availability was studied through Principal Component Analysis (PCA) biplot and hierarchical clustering. The percentage increase in livestock, fodder resources, and biomass availability by category of households in 2016 was subjected to a PCA biplot analysis (mean vs. stability, discriminativeness vs. representativeness and ranking genotype view) and hierarchical clustering. Data was analysed using SASv9.4 (SAS Institute, 2016) and R statistical software (R Core Team, 2016). The data was presented in PCA biplots. The different variables, i.e., bovine population, forage resources, and biomass availability were studied based on household farm size (marginal, small, semi-medium, medium and large) in a fixed effects model. A multivariate stability statistics was also computed using the PCA (biplot) package with the support of R studio (RStudio Team, 2014). In this study, the interaction between farmer category and variables was computed, and the variables were ranked based on stability and mean (Yan and Kang,
(Oladosu et al., 2017). Hierarchical clustering analysis of the bovine population, forage resources, and biomass availability were carried out with $\mathrm{R}$ statistical software using Ward's minimum variance technique. Clustering of these parameters was done on the basis of the impact of watershed interventions.

\section{Results}

\subsection{Impact of watershed interventions on groundwater availability}

Fig. 2 shows the functioning of the dug wells and the rainfall distribution between 2011 and 2016. The functioning of the dug wells was split into five categories based on the pressure head (h): dry = no water, poor $\leq 1 \mathrm{~m}$, medium $=1-3 \mathrm{~m}$, good $=3-5 \mathrm{~m}$, and very good $\geq 5 \mathrm{~m}$. During the project period, year 2011 and 2013 were wet years which received $1189 \mathrm{~mm}$ and $1276 \mathrm{~mm}$ rainfall, respectively. The years 2012 and 2016 were normal years with $825 \mathrm{~mm}$ and $768 \mathrm{~mm}$ rainfall, respectively. The years 2014 and 2015 were dry and very dry years, with $520 \mathrm{~mm}$ and $404 \mathrm{~mm}$ rainfall, respectively. Years 2011 and 2012 were considered as the pre-development phase, whereas by 2013 over $70 \%$ of rainwater harvesting structures were completed, with the haveli being the major structure with $73,000 \mathrm{~m}^{3}$ storage capacity. A comparison of the status of functioning dug wells in wet years before (2011) and during (2013) watershed interventions revealed that despite receiving similar quantum of rainfall, only about 60\% in July 2011 and 25\% in December 2011 had very good water status. In 2013, 90\% of the wells were functioning very well in August and $85 \%$ in December. Once the groundwater was recharged to its full potential in 2013, water availability extended to two consecutive dry years (i.e., up to December 2015). The wells started drying up only after December 2015, one of the driest years. Further, a comparison of the two normal years (before 2012 


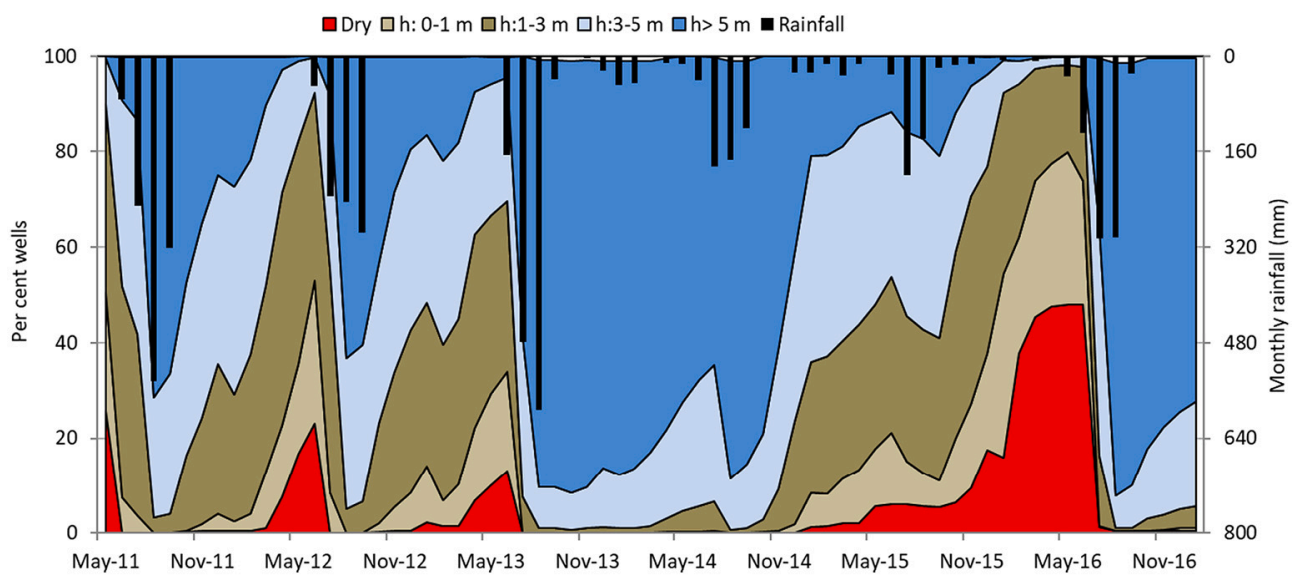

Fig. 2. The status of 338 dug wells monitored on a monthly basis in Parasai-Sindh watershed and rainfall between 2011 and 2016. (h symbolizes pressure head in legend).

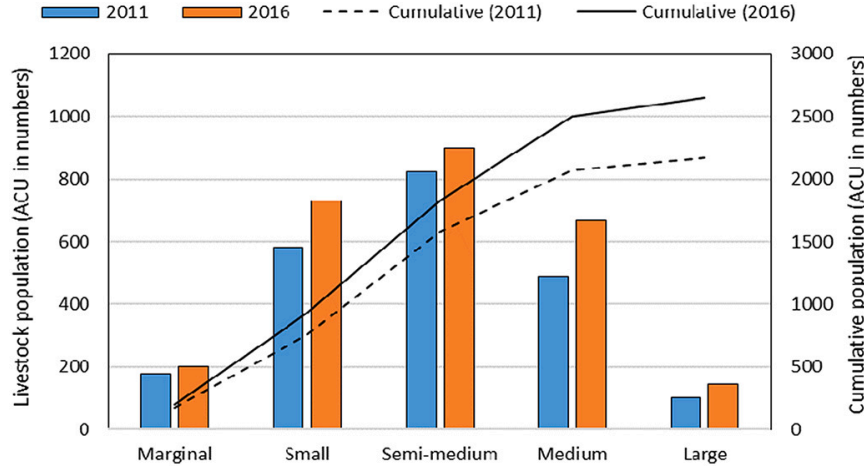

Fig. 3. Impact of watershed management on livestock population (ACUs) across different farmer categories.



Fig. 4. Impact of watershed management on milk production per year across different farmer categories in the study watershed.

and after 2016) also witnessed similar results. For example, by the end of December 2012, the pressure head was very good in $19 \%$ of the dug wells, good in $38 \%$, medium in $34 \%$ and poor in $9 \%$ of them while in December 2016 , it was very good in $74 \%$, good in $20 \%$, medium in $4 \%$ and poor in $2 \%$ of them. This clearly indicates that groundwater availability has improved immensely across the watershed villages during and post-project interventions.

\subsection{Impact of watershed interventions on livestock population and milk yield}

On an average, there were 5.2 ACUs/household during 2011 (preintervention) and 6.4 ACUs/household during 2016 (post-intervention), registering a $22 \%$ increase in livestock population over the five-year period in the watershed area. The ACUs/household in the pre- and post-intervention periods were 2.2 and 2.5 for marginal, 4.0 and 5.0 for small, 7.1 and 7.8 for semi-medium, 9.8 and 13.4 for medium, and 20.5 and 29.1 for large farm households, respectively. This indicates a $9-42 \%$ increase in ACUs among the different household categories (Fig. 3). An increase in milk yield of $198 \%$ was recorded among marginal farmers, $152 \%$ among small farmers, and more than $90 \%$ among semi-medium, medium, and large farmers (Fig. 4). Overall, milk yield increased by $120 \%$ during 2016 compared to the pre-watershed period. The oxen population in the watershed however fell from 298 (2011) to 69 (2016) indicating a change in farmers' choice, largely due to farm mechanization. Similarly, sheep and goat populations decreased substantially. Among the bovines, cattle population saw a 193\% increase from 215 ACUs (2011) to 630 ACUs (2016), while the buffalo population grew by $32 \%$ from 1329 ACUs in 2011 to 1760 ACUs in 2016 (Table 4 and Fig. 3). It was also observed that providing water and feed to the animals and other management practices were mostly carried out by women; however these practices were not influenced by the farm typologies.

The PCA biplot (mean vs. stability) analysis of livestock population in different household farm categories explained the $97.1 \%$ treatment and treatment vs. environmental variation. In Fig. 5.1a, the average environment coordinate (AEC) had one direction, with the arrow pointing to greater category effect on singular partitioning value (SVP = 1). Evidently, the highest mean performance with respect to cattle population was observed among medium sized landholding farmers, followed by that of large farmers. The hierarchical clustering analysis also recorded the maximum increase in cattle population among medium sized landholders (Fig. 6a). However, highest increase in buffalo population was observed among small landholders followed by marginal landholders, which is the major factor for increased milk production with these categories of households. Higher stability, however, was observed with marginal and semi-medium landholders. In Fig. 5.1b, cattle population had the highest discriminativeness (informative) across the environments. Cattle were most discriminative in the first mega-environment, while buffalo was in the second mega-environment. The representativeness of a test parameter (livestock category) referred to the consistency of a targeted parameter when compared with other parameters or the means of all the test livestock categories. In this case, the tested parameters were classified into two mega-environments based on representativeness as shown in Fig. 5.1b. Cattle were the most 
Table 4

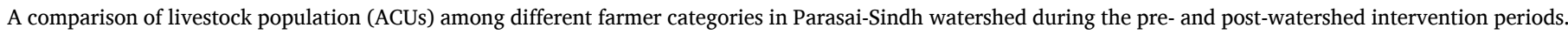

\begin{tabular}{|c|c|c|c|c|c|c|c|c|c|c|c|c|}
\hline \multirow[t]{2}{*}{ Farmer category } & \multicolumn{2}{|l|}{ Cattle } & \multicolumn{2}{|l|}{ Oxen } & \multicolumn{2}{|c|}{ Buffalo } & \multicolumn{2}{|l|}{ Sheep } & \multicolumn{2}{|l|}{ Goat } & \multicolumn{2}{|l|}{ Total } \\
\hline & 2011 & 2016 & 2011 & 2016 & 2011 & 2016 & 2011 & 2016 & 2011 & 2016 & 2011 & 2016 \\
\hline Marginal & 25 & $62\left(148 \%{ }^{*}\right)$ & 31 & $9(-71 \%)$ & 81 & $115(42 \%)$ & 13 & $5(-62 \%)$ & 27 & $11(-59 \%)$ & 178 & $202(13 \%)$ \\
\hline Small & 72 & $182(153 \%)$ & 130 & $24(-82 \%)$ & 291 & $448(54 \%)$ & 26 & $25(-4 \%)$ & 63 & $51(-19 \%)$ & 581 & $730(26 \%)$ \\
\hline Semi-medium & 62 & $152(145 \%)$ & 92 & $21(-77 \%)$ & 506 & $650(28 \%)$ & 81 & $26(-68 \%)$ & 84 & $52(-38 \%)$ & 824 & 902 (9\%) \\
\hline Medium & 45 & $194(331 \%)$ & 39 & $9(-77 \%)$ & 372 & $447(20 \%)$ & 14 & $4(-71 \%)$ & 20 & $15(-25 \%)$ & 490 & 669 (37\%) \\
\hline Large & 11 & $41(273 \%)$ & 7 & $5(-29 \%)$ & 79 & $99(25 \%)$ & 2 & $0(-100 \%)$ & 3 & $1(-67 \%)$ & 103 & $146(42 \%)$ \\
\hline Total & 215 & $630(193 \%)$ & 298 & $69(-77 \%)$ & 1329 & $1759(32 \%)$ & 136 & $61(-55 \%)$ & 197 & $129(-35 \%)$ & 2175 & $2648(22 \%)$ \\
\hline
\end{tabular}

* Values in parentheses are percentage change in livestock population compared to the baseline.

representative ones with medium and large category landholders. Buffalo population is the closest to the point, hence becomes the best parameter, which increased in marginal, small and semi-medium categories. Goat and sheep populations decreased the least with small landholders. As shown in Fig. 5.1c, buffalo, sheep, and goat populations was ranked first with small landholders, while cattle and oxen were ranked first with medium and large landholders.

\subsection{Impact of watershed interventions on forage resources}

Crop residue, weed biomass and grasses on wasteland, and earthen field bunds were the major forage sources of livestock in Parasai-Sindh watershed. The area under different forage resources (kharif, rabi and other sources) during 2011 and 2016 are presented in Table 5. About $70 \%$ of the total area under agricultural use (groundnut, black gram, green gram and fodder) in 2011 increased to $80 \%$ in 2016 and land under fallow decreased from $11 \%$ to $4 \%$ in 2016 . In addition, the area under degraded wasteland and field bunds increased from 4\% in 2011 to $6 \%$ in 2016. During the rabi season, the area under wheat increased from $47 \%$ in 2011 to $78 \%$ in 2016 , and a marginal increase in the area under barley from $2 \%$ to $4 \%$ was observed. It is to be noted that the increase in cultivable area under wheat came mainly from fallow land (23\% in 2011 to $1 \%$ in 2016).

Mean vs. stability, discriminativeness vs. representativeness and ranking genotype analysis of forage resources in different household categories explained $98.8 \%$ of the treatment and treatment vs. environmental variation. Higher stability of forage resources was observed among semi-medium farmers followed by marginal farmers. Drainage network, barley, kharif fodder, and groundnut performed better as forage resources under marginal farmers (Fig. 5.2a and Fig. 6b). Forage resources from bunds and wheat increased under small, medium, and large farmers. Forage resources on bunds showed highest discriminativeness, followed by the drainage network (Fig. 5.2b). Across the environments, the drainage network ranked first, followed by barley, kharif fallow and groundnut in terms of forage resources (Fig. 5.2c), while bunds and wheat ranked in small, medium and large category farmers.

\subsection{Impact of watershed interventions on forage biomass production}

Crop residues were the major source of forage biomass in the study site (Table 6). During pre- watershed interventions (2011), total annual forage biomass production was 4219 t DM, which increased by $65 \%$ to $6977 \mathrm{t} \mathrm{DM}$ in 2016. Average annual household forage biomass production to feed livestock also increased from $10 \mathrm{t} \mathrm{DM}$ in 2011 to $17 \mathrm{t} \mathrm{DM}$ in 2016 in the watershed area. The difference in forage production between 2011 and 2016 was estimated at 2758 t DM, of which $82 \%$ came from increased wheat acreage during the rabi season, $15 \%$ was from green fodder production in the kharif season, $9 \%$ from an increase in groundnut area while the contribution of other crops fell by 7\%. Table 6 also describes the variability in forage production among different farmer categories. An increase in forage production was realised by semi-medium farmers (1007 t DM) followed by medium (776 t DM) and small (669 t DM) farmers.

Stability in biomass availability among small and large farmers was high compared to semi-medium, medium and marginal farmers (Fig. 5.3a). The PCA biplot of biomass availability explained the $96.8 \%$ treatment, treatment $\times$ environment variations. All the resources for biomass production were categorized in four mega-environments of farmer categories. The highest increase in fodder production was observed among medium farmers, from bunds (Fig. 6c). The drainage network's contribution increased substantially in the marginal farmer category. Likewise, bunds and drainage networks showed comparatively higher discriminativeness among marginal and medium category farmers, respectively. However, groundnut, black gram, green gram, wheat, chickpea and degraded forest and wastelands recorded higher representativeness compared to other forage resources in terms of biomass availability (Fig. 5.3b). Drainage networks for marginal farmers, bunds for medium category farmers, and wheat for small, semimedium and large farmers ranked first in terms of increase in biomass as well as its availability after the watershed interventions in the area (Fig. 5.3c).

\subsection{Bridging the forage supply-demand gap}

Based on total livestock population (ACU), available forage biomass and forage demand and supply in the watershed area were estimated for the pre- and post-watershed periods (Fig. 7). Annual fodder demand in 2011 was $5560 \mathrm{t} \mathrm{DM}$ to feed $2175 \mathrm{ACU}$, which increased to $6770 \mathrm{t} \mathrm{DM}$ to feed $2650 \mathrm{ACU}$ in 2016. Annual forage availability was estimated at 4219 t DM in 2011 and 6977 t DM in 2016. There was an annual deficit of $1341 \mathrm{t} \mathrm{DM}$ in 2011. However, project interventions led to an increase in forage production, with a surplus of 210 t DM/year in 2016.

Fig. 7 shows that there is still a deficit in forage among small and marginal farmers while semi-medium, medium, and large farmers are producing surplus fodder; hence fodder is traded between surplus producers and deficit producers. It was also noted that only large farmers had surplus forage $(10.6 \%)$ during pre-watershed interventions, while there was a substantial deficit of about $50 \%, 32 \%, 33 \%$ and $6 \%$ in the case of marginal, small, semi-medium, and medium farmers, respectively. After the watershed interventions, demand for forage was largely met despite the increase in livestock population, except for the $10-20 \%$ unmet demand for marginal and small farmers.

\subsection{Impact on household net income}

Before the interventions, average net household income was US\$ 1325 /year, of which $83 \%$ (i.e., US\$ 1100 /household) came from agriculture and $17 \%$ (US\$ $225 /$ household) from milk production. After the project interventions, the average net household income recorded was US\$ 2430 /year, of which $80 \%$ (US\$ 1940/household) came from agriculture and $20 \%$ (US\$ 490/household) from milk production. Therefore, the gain in net income was US\$1105/household, which is $84 \%$ higher than the baseline. Fig. 8 further compares annual net income generated from agriculture (kharif and rabi seasons) and livestock (milk production) among different category of farmers before and after the watershed 




$5.1 \mathrm{a}$

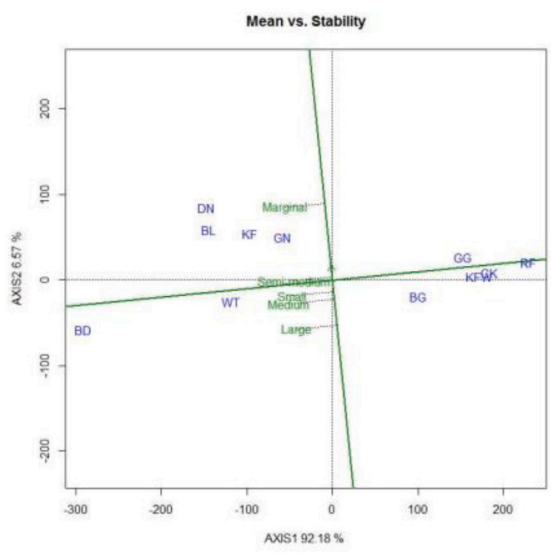

$5.2 a$



$5.3 a$

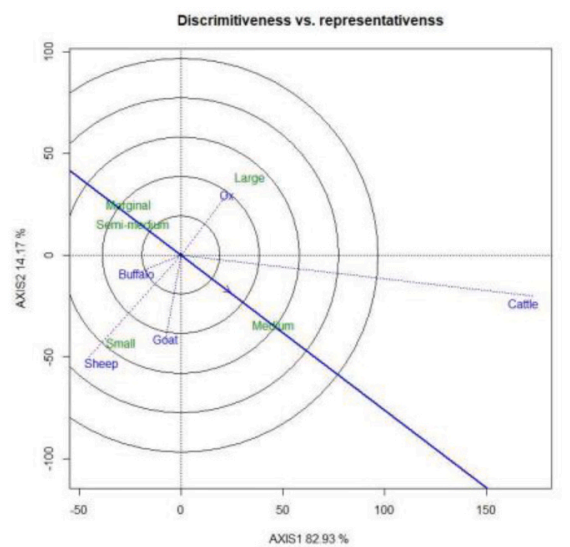

$5.1 b$



$5.2 b$

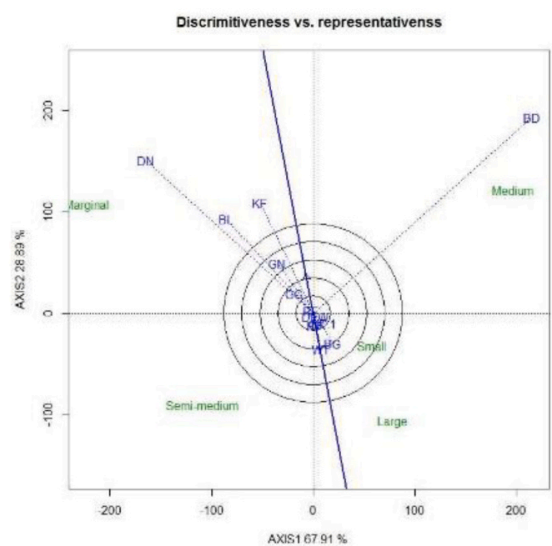

$5.3 b$

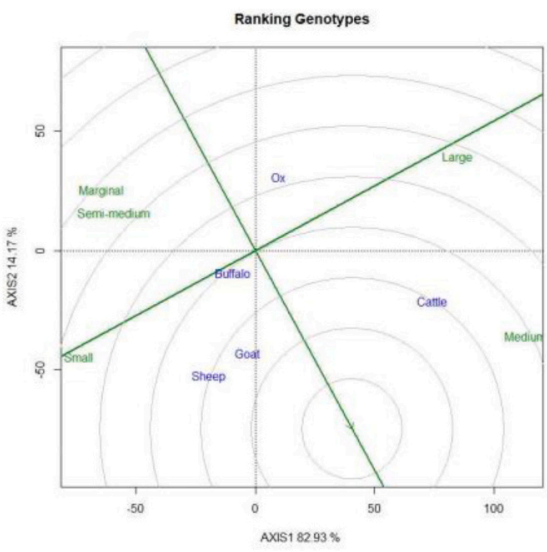

$5.1 \mathrm{c}$



$5.2 \mathrm{c}$



$5.3 c$

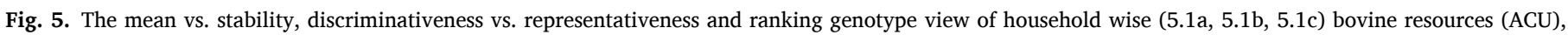

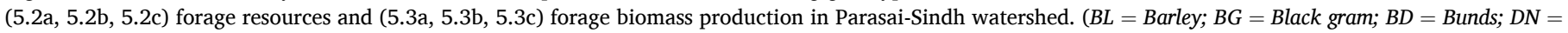

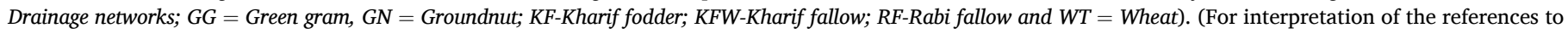
colour in this figure legend, the reader is referred to the web version of this article.) 




a)

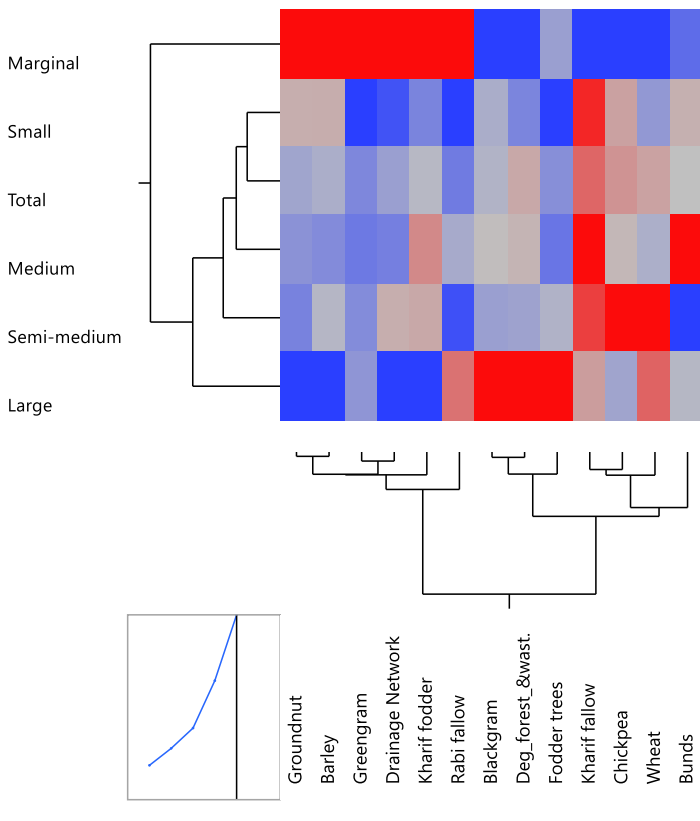

c)

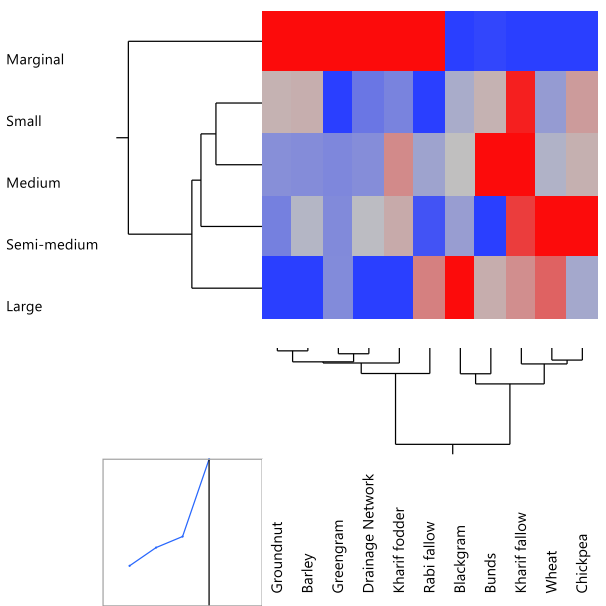

b)

Fig. 6. Hierarchical clustering of (a) bovine, (b) forage resources and (c) biomass availability in Parasai-Sindh watershed.

interventions. There was a significant variation in net income among different farmer categories due to landholding size. It is important to note that these farmers have benefited in proportion to their landholding size. While there was a marginal increase $(\sim 30 \%)$ in net income during the kharif season; the difference in net income was significant ( $>200 \%$ ) during the rabi season. In addition, with increased rabi season production and fodder availability, gain in net income due to milk production ranged from 90 to $200 \%$ among different categories of farmers compared to before the interventions. In total, the annual net income of marginal, small, semi-medium, medium, and large farmers increased by US\$ 385 (96\%), US\$ 770 (88\%), US\$ 1330 (82\%), US\$ 2435 (80\%), and US\$ 4520 (79\%) per household, respectively.

\section{Discussion}

\subsection{Sustainable crop intensification and diversification through} watershed interventions

Moisture availability is critical to sustainable crop production in the drylands. Due to the soil's poor moisture retention ability, a significant area in the uplands remains fallow permanently or seasonally. In-situ as well as ex-situ interventions that were implemented across the watershed have facilitated the recharge of shallow groundwater aquifers, especially during normal and wet years. Despite experiencing two consecutive dry years (2014 and 2015), groundwater recharged in 2013 has sustained the production system even in dry years. Households with livestock did not suffer due to water scarcity in terms of drinking water and remained dependent on their own wells. This clearly indicates the resilience built through watershed interventions which ensured water 
Table 5

A comparison of forage resources of different farmer categories in Parasai-Sindh watershed during the pre- and post-intervention periods.

\begin{tabular}{|c|c|c|c|c|c|c|c|c|c|c|c|c|}
\hline \multirow[t]{3}{*}{ Forage resources (ha/year) } & \multicolumn{10}{|c|}{ Farmer category } & & \\
\hline & \multicolumn{2}{|c|}{ Marginal } & \multicolumn{2}{|l|}{ Small } & \multicolumn{2}{|c|}{ Semi-medium } & \multicolumn{2}{|c|}{ Medium } & \multicolumn{2}{|l|}{ Large } & \multicolumn{2}{|l|}{ Total } \\
\hline & 2011 & 2016 & 2011 & 2016 & 2011 & 2016 & 2011 & 2016 & 2011 & 2016 & 2011 & 2016 \\
\hline \multicolumn{13}{|l|}{ Kharif season } \\
\hline Groundnut & 33.8 & 61.5 & 162.3 & 223.8 & 250.3 & 301.6 & 199.0 & 246.3 & 46.7 & 49.9 & 692.0 & 883.0 \\
\hline Black gram & 6.5 & 3.1 & 28.1 & 17.8 & 43.0 & 26.4 & 33.6 & 22.3 & 5.9 & 5.4 & 117.0 & 75.0 \\
\hline Green gram & 2.3 & 1.3 & 11.8 & 4.1 & 15.5 & 6.0 & 13.6 & 5.2 & 3.8 & 1.5 & 47.0 & 18.0 \\
\hline Kharif fodder & 0.8 & 1.5 & 4.7 & 6.1 & 5.5 & 8.6 & 4.2 & 7.0 & 1.8 & 1.9 & 17.0 & 25.0 \\
\hline Kharif fallow & 10.4 & 2.5 & 31.8 & 11.6 & 48.7 & 17.4 & 40.3 & 14.8 & 10.9 & 3.8 & 142.0 & 50.0 \\
\hline Sub-total (A) & 53.7 & 69.9 & 238.8 & 263.4 & 362.9 & 360.0 & 290.6 & 295.5 & 69.1 & 62.3 & 1015.0 & 1051.0 \\
\hline \multicolumn{13}{|l|}{ Rabi season } \\
\hline Wheat & 35.3 & 52.4 & 142.5 & 227.6 & 195.0 & 349.4 & 172.3 & 280.3 & 37.9 & 65.2 & 583.0 & 975.0 \\
\hline Chickpea & 6.4 & 1.2 & 19.5 & 5.8 & 25.8 & 9.3 & 24.1 & 6.9 & 7.2 & 1.9 & 83.0 & 25.0 \\
\hline Barley & 1.4 & 3.1 & 6.4 & 11.5 & 10.8 & 18.3 & 9.1 & 14.2 & 2.3 & 3.0 & 30.0 & 50.0 \\
\hline Rabi fallow & 11.9 & 1.1 & 78.4 & 4.0 & 107.9 & 5.8 & 77.9 & 5.0 & 16.0 & 1.2 & 292.0 & 17.1 \\
\hline Sub-total (B) & 55.0 & 57.9 & 246.8 & 248.8 & 339.4 & 382.7 & 283.4 & 306.3 & 63.4 & 71.4 & 988.0 & 1067.0 \\
\hline \multicolumn{13}{|l|}{ Other sources } \\
\hline Degraded forest and wasteland & 1.5 & 1.5 & 8.2 & 8.2 & 12.8 & 12.8 & 9.5 & 9.5 & 4.0 & 4.0 & 36.0 & 36.0 \\
\hline Bunds & 1.1 & 2.4 & 4.2 & 10.3 & 7.2 & 15.3 & 4.2 & 12.0 & 1.2 & 2.9 & 17.8 & 42.8 \\
\hline Drainage network & 0.1 & 0.2 & 0.6 & 0.8 & 0.7 & 1.2 & 0.6 & 0.9 & 0.2 & 0.2 & 2.0 & 3.3 \\
\hline Sub-total (C) & 2.7 & 4.2 & 13.0 & 19.3 & 20.7 & 29.3 & 14.2 & 22.3 & 5.3 & 7.0 & 55.9 & 82.1 \\
\hline Total $(\mathrm{A}+\mathrm{B}+\mathrm{C})$ & 111.3 & 131.9 & 498.6 & 531.5 & 723.0 & 771.9 & 588.2 & 624.1 & 137.8 & 140.7 & 2058.9 & 2200.1 \\
\hline
\end{tabular}

Table 6

A comparison of biomass availability from crop residue among different categories of farmers during the pre- and post-intervention periods.

\begin{tabular}{|c|c|c|c|c|c|c|c|c|c|c|c|c|}
\hline \multirow[t]{3}{*}{ Forage biomass (t DM/year) } & \multicolumn{10}{|c|}{ Farmer category } & & \\
\hline & \multicolumn{2}{|c|}{ Marginal } & \multicolumn{2}{|l|}{ Small } & \multicolumn{2}{|c|}{ Semi-medium } & \multicolumn{2}{|l|}{ Medium } & \multicolumn{2}{|l|}{ Large } & \multicolumn{2}{|l|}{ Total } \\
\hline & 2011 & 2016 & 2011 & 2016 & 2011 & 2016 & 2011 & 2016 & 2011 & 2016 & 2011 & 2016 \\
\hline \multicolumn{13}{|l|}{ Kharif season } \\
\hline Groundnut & 58.7 & 101.8 & 282.0 & 370.6 & 434.9 & 499.6 & 345.7 & 407.9 & 81.2 & 82.6 & 1202.5 & 1462.6 \\
\hline Black gram & 2.7 & 1.4 & 11.9 & 7.8 & 18.2 & 11.5 & 14.2 & 9.7 & 2.5 & 2.3 & 49.5 & 32.7 \\
\hline Green gram & 0.8 & 0.7 & 4.3 & 2.2 & 5.7 & 3.2 & 5.0 & 2.8 & 1.4 & 0.8 & 17.2 & 9.7 \\
\hline Kharif fodder & 15.6 & 46.1 & 94.7 & 183.3 & 109.6 & 256.4 & 84.7 & 208.4 & 35.4 & 55.9 & 340.0 & 750.0 \\
\hline Kharif fallow & 18.2 & 6.3 & 55.6 & 28.9 & 85.1 & 43.6 & 70.5 & 37.0 & 19.1 & 9.4 & 248.5 & 125.0 \\
\hline Sub-total (A) & 96.0 & 156.2 & 448.6 & 592.8 & 653.6 & 814.3 & 520.0 & 665.8 & 139.6 & 151.0 & 1857.7 & 2380.0 \\
\hline \multicolumn{13}{|l|}{ Rabi season } \\
\hline Wheat & 100.9 & 211.9 & 406.9 & 921.0 & 556.7 & 1413.6 & 492.1 & 1133.9 & 108.2 & 264.0 & 1664.7 & 3944.3 \\
\hline Chickpea & 14.1 & 2.7 & 43.0 & 12.5 & 56.7 & 20.1 & 52.9 & 14.9 & 15.9 & 4.1 & 182.6 & 54.2 \\
\hline Barley & 2.9 & 10.5 & 13.8 & 38.4 & 23.0 & 61.2 & 19.4 & 47.6 & 4.8 & 10.0 & 64.0 & 167.6 \\
\hline Rabi fallow & 11.9 & 1.7 & 78.4 & 6.0 & 107.9 & 8.6 & 77.9 & 7.5 & 16.0 & 1.9 & 292.0 & 25.6 \\
\hline Sub-total (B) & 129.7 & 226.7 & 542.0 & 977.8 & 744.3 & 1503.5 & 642.3 & 1203.8 & 145.0 & 279.9 & 2203.3 & 4191.8 \\
\hline \multicolumn{13}{|l|}{ Other sources } \\
\hline Degraded forest and wasteland & 1.5 & 2.2 & 8.2 & 12.3 & 12.8 & 19.3 & 9.5 & 14.3 & 4.0 & 6.0 & 36.0 & 54.0 \\
\hline Bunds & 1.1 & 12.2 & 4.2 & 51.3 & 7.2 & 76.3 & 4.2 & 59.9 & 1.2 & 14.3 & 17.8 & 214.0 \\
\hline Drainage network & 0.2 & 1.4 & 1.1 & 4.9 & 1.3 & 6.9 & 1.1 & 5.2 & 0.3 & 1.3 & 4.0 & 19.7 \\
\hline Fodder trees & 9.6 & 11.3 & 29.7 & 33.9 & 33.3 & 39.6 & 22.4 & 26.1 & 5.4 & 7.2 & 100.3 & 118.0 \\
\hline Sub-total (C) & 12.4 & 27.0 & 13.5 & 102.4 & 54.6 & 142.1 & 37.2 & 105.4 & 10.9 & 28.7 & 158.2 & 405.6 \\
\hline Total $(\mathrm{A}+\mathrm{B}+\mathrm{C})$ & 238.1 & 409.9 & 1004.0 & 1673.0 & 1452.5 & 2459.9 & 1199.5 & 1975.0 & 295.4 & 459.6 & 4219.2 & 6977.4 \\
\hline
\end{tabular}

security for both human and livestock populations.

With assured water availability in shallow dug wells, farmers were motivated to cultivate their land in two seasons in a year. Moreover, the land which was left fallow permanently was brought into cultivation, making a significant change in crop and fodder production. In this process, farmers realised better production and returns from agriculture and they diversified livestock as per their landholdings and carrying capacity of the fields. However, only small and marginal farmers have intensified livestock activities to a large extent as they obtained financial returns on a daily basis. Consequently, they gradually increased their cow and buffalo populations and reduced the number of small ruminants. The increased cattle and buffalo populations were due to greater availability of forage biomass, while mechanization has led to decreased oxen population. With an increase in land area under cultivation and additional income, farmers were able to afford mechanization. The reduced fallow and pasture lands around the villages were also some reasons for the decline in small ruminant numbers.

It is also important to note that despite the low livestock population, the landscape was not able to support their fodder needs before the watershed interventions. Now the same land resources are able to generate surplus forage despite a $22 \%$ increase in livestock population compared to the baseline. Cattle and buffalo populations increased and those of oxen and bovines decreased after the watershed interventions.

\subsection{Conversion of fallow land opens up opportunities for crop intensification}

About $15 \%$ of the agricultural land remained fallow before the watershed interventions, producing a limited quantity of fodder and available for open grazing. This area has now been put to productive cultivation with assured water availability. A fraction of the runoff which is harvested in rainwater harvesting structures and later in 


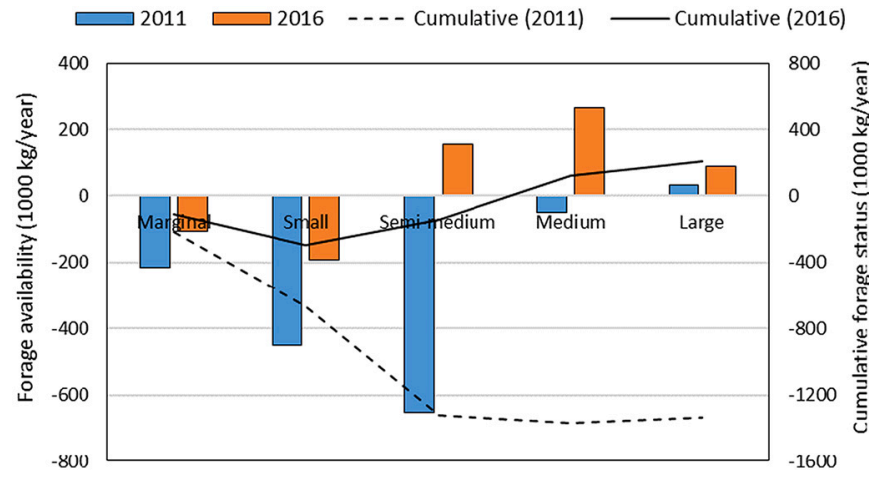

Fig. 7. Forage availability by farmer category before and after the watershed interventions.

groundwater aquifers, is only $10-15 \%$ of the total consumptive water use from the system. Most of the soil moisture which was earlier lost as non-productive evaporation from fallow land has turned into productive evapotranspiration after the project intervention (Singh et al., 2021). However, the increased groundwater has acted as a catalyst to use available resources in the watershed. This phenomenon, defined as vapour shift by Rockström (2003), shows that enhancing crop production does not always mean the utilization of natural resources in the same proportion, which could be achieved by enhancing resource use efficiency. Therefore, natural resource management interventions have the potential to address this issue.

In this case, changes in crop and fodder production were realised during the rabi season, which was also reflected in the net income of farmers compared to the pre-intervention period. With increased groundwater availability, farmers were encouraged to cultivate rabi season crops even in the uplands; which were otherwise left permanently fallow. This resulted in increased dry fodder availability in the watershed. Crop intensification and higher productivity have together contributed to the near doubling of net household income compared to the baseline level. However, large farmers benefited more due to their landholding size while at the same time small and marginal farmers benefited in terms of employment opportunities within the villages besides their increased income from agriculture and livestock activities. The systematic changes in the watershed in terms of ensuring water availability led to the conversion of permanent fallow land to productive cultivation and seasonal fallows to intensified cultivation. Based on the focus group discussion, it was revealed that increased cropping intensity generated sufficient employment opportunities for both landholders and landless farmers. In addition, increased groundwater availability from rainwater harvesting interventions nullified the impact of droughts (Garg et al., 2020b; Singh et al., 2021). This has arrested the seasonal migration in this watershed.

\subsection{Comparison with other studies and future scope}

Most studies on the impact of watershed interventions have focused on water harvesting and crop production, with a limited understanding of water-crop-livestock interactions. A limited number of studies have attempted to address crop-livestock system dynamics in the watershed context. Arya et al. (2011) reported a reduction in goat population and increased stall-fed buffaloes as a result of the implementation of a watershed programme in the Shivalik foothills of India. In a study on Garhkundar Dabar watershed in Madhya Pradesh, Singh et al. (2014) reported increased surface and groundwater availability which led to a change in cropping pattern from pulses to wheat and thereby increased biomass availability for livestock. In all, water is the most essential requirement in any production system and its improved availability across time and space in the watershed areas enables productivity vis-avis biomass availability to overcome forage deficit (Sreedevi et al., 2006).

Despite the increase in forage resources, watershed interventions also provide a congenial ecosystem for healthy and productive livestock (Descheemaeker et al., 2010), which encourages farmers to opt for livestock farming. The trends clearly indicated that natural resource management interventions in the watershed had brought more area under bunds and drainage networks, thereby enhancing fodder production.

\section{Conclusion}

This paper analysed the interaction between water-crop-livestock sectors in a fragile ecoregion of central India. The agriculturedominated watershed on 1250 ha was treated with a range of natural resource management interventions between 2012 and 2016 and constantly monitored. Following are findings of the study:

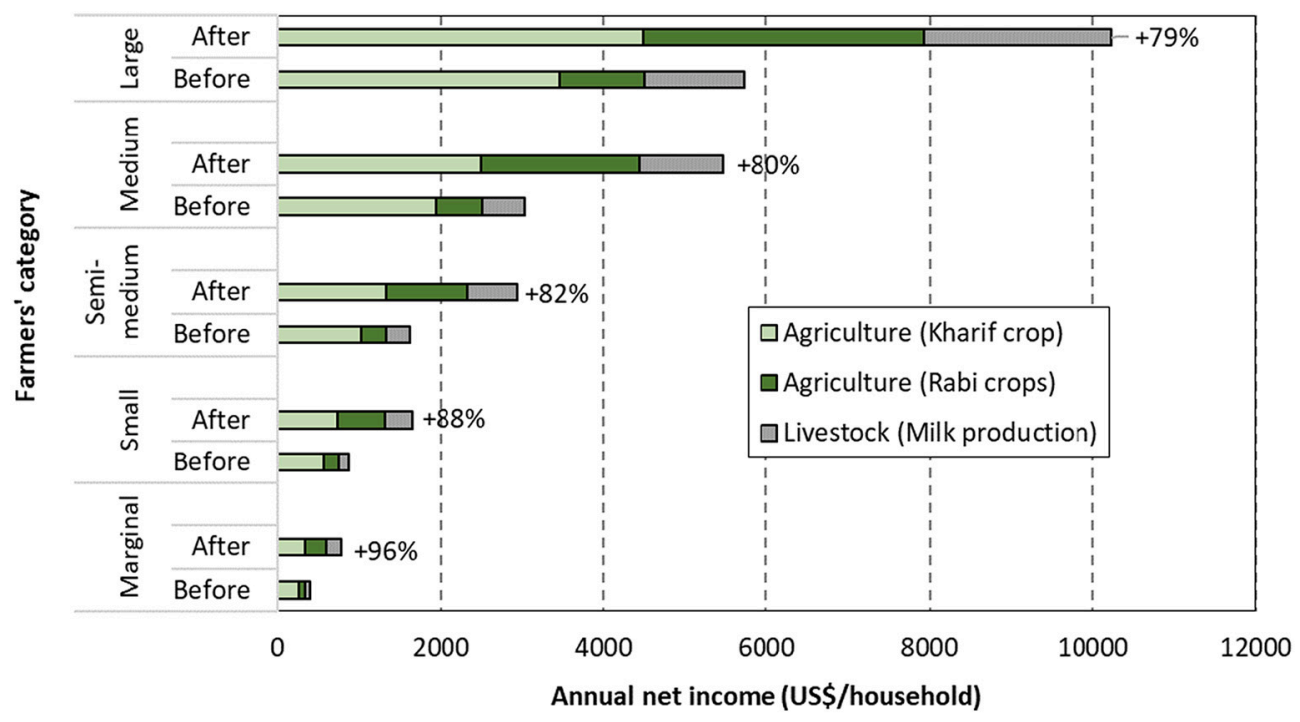

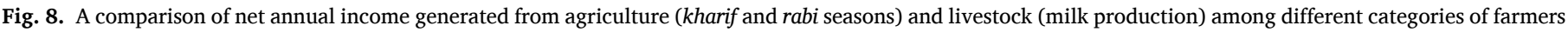
before and after the watershed interventions. 
- The decentralized rainwater harvesting interventions improved groundwater level even in the summer. Groundwater recharge during the wet year supported agriculture in two consecutive dry years. Improved water availability intensified the cropping system as about $15 \%$ of permanent fallow land was turned into productive cultivation and seasonal fallows were used for double cropping.

- The livestock population in the watershed increased by $22 \%$ in a five-year period and milk production increased by $120 \%$. The difference in forage production between 2011 and 2016 was estimated at $2758 \mathrm{t} \mathrm{DM}$, of which $82 \%$ came from increased wheat acreage during the rabi season, $15 \%$ from green fodder production in the kharif season, $9 \%$ from an increase in groundnut area while the contribution from other crops fell by $7 \%$.

- With 2175 ACUs, the annual fodder deficit was $24 \%$ than the demand (5560 t DM) which has converted into 3\% surplus production (6977 t DM) with increased livestock population of 2650 ACUs after the project intervention. Among all the five categories of farmers, small and marginal farmers had a $10-20 \%$ forage deficit which was compensated by the surplus forage from semi-medium, medium, and large category farmers. Small and marginal farmers have diversified their livestock portfolio into cows and buffaloes with assured water availability and reduced their risk of crop failure.

- With crop intensification and higher productivity, average annual household income increased by US $\$ 1100$ compared to the pre-project period, of which 53\% came from rabi season agriculture and $24 \%$ from milk production.

- Natural resource management interventions were the key contributors to transforming the degraded landscape into productive agriculture which supports the livestock sector, leading to diversifying household income sources in the dryland ecosystem.

The study's results underline the promise that integrated watershed management holds in addressing the challenges of dryland areas towards meeting the United Nations Sustainable Development Goals (SDGs) in fragile ecologies of Asia and Africa.

\section{Declaration of Competing Interest}

None.

\section{Acknowledgements}

The authors acknowledge the support provided by ICAR-Central Agroforestry Research Institute, Jhansi, India and ICRISAT, Hyderabad, India to carry out the study. Our thanks also go to the farmers of the Parasai-Sindh watershed for their support in carrying out this study. We sincerely acknowledge the funding support received from Government of Uttar Pradesh and CGIAR Research Program -Water, Land and Ecosystem (CRP-WLE) for undertaking the monitoring and impact study.

\section{References}

20th Livestock census, 2019. Integrated Sample Survey [WWW Document]. URL. http:// www.dahd.nic.in/about-us/divisions/statistics.

Ali, J., 2007. Livestock sector development and implications for rural poverty alleviation in India. Livest. Res. Rural. Dev. 19, 1-14.

Anantha, K.H., Garg, K.K., Moses, D.S., Patil, M.D., Sawargaonkar, G.L., Kamdi, P.J., Malve, S., Sudi, R., Raju, K.V., Wani, S.P., 2021a. Impact of natural resource management interventions on water resources and environmental services in different agroecological regions of India. Groundw. Sustain. Dev. 13 https://doi.org/ 10.1016/j.gsd.2021.100574.

Anantha, K.H., Garg, K.K., Petrie, C.A., Dixit, S., 2021b. Seeking sustainable pathways for fostering agricultural transformation in peninsular India. Environ. Res. Lett. 16, 1-14. https://doi.org/10.1088/1748-9326/abed7b.
Arya, S.L., Panwar, P., Yadav, R.P., 2011. Role of watershed Management in Bridging Demand - supply gap of fodder for enhancing livestock production in Shivaliks, Haryana. Agric. Econ. Res. 24, 225-233.

Bharucha, Z.P., 2019. This is what nature has become: tracing climate and water narratives in India's rainfed drylands. Geoforum 101, 285-293. https://doi.org/ 10.1016/j.geoforum.2018.09.032.

Birthal, P.S., Taneja, V.K., Thorpe, W.R., 2006. Livestock Sector in India: Opportunities and Challenges for Smallholders, in: IICAR-ILRI Nternational Workshop on 'Smallholder Livestock Production in India: Opportunities and Challenges.

Chikwanha, O.C., Mupfiga, S., Olagbegi, B.R., Katiyatiya, C.L.F., Molotsi, A.H., Abiodun, B.J., Dzama, K., Mapiye, C., 2021. Impact of water scarcity on dryland sheep meat production and quality: key recovery and resilience strategies. J. Arid Environ. 190, 104511.

Descheemaeker, K., Mapedza, E., Amede, T., Ayalneh, W., 2010. Effects of integrated watershed management on livestock water productivity in water scarce areas in Ethiopia. Phys. Chem. Earth 35, 723-729. https://doi.org/10.1016/j. pce.2010.06.006.

Dev, I., Misri, B., Pathania, M.S., 2006. Forage demand and supply in western Himalaya: a balance sheet for Himachal Pradesh. Indian J. Anim. Sci. 76, 720-726.

Dev, I., Ahlawat, S.P., Palsaniya, D.R., Ram, A., Newaj, R., Tewari, R.K., Singh, R., Sridhar, K.B., Dwivedi, R.P., Srivastava, M., Chaturvedi, O.P., Kumar, R.V., Yadav, R. S., 2016. A sustainable livelihood option for farmers' of semi-arid region : bamboo + chickpea based agroforestry model. Indian J. Agrofor. 18, 84-89.

Dev, I., Radotra, S., Ram, A., Singh, J.P., Deb, D., Roy, M.M., Srivastava, M., Kumar, P., Ahmad, S., Chaurasia, R.S., 2018. Species richness, productivity and quality assessment of grassland resources in hill agroecosystem of western Himalaya. Indian J. Anim. Sci. 88, 1167-1175.

Dev, I., Ram, A., Ahlawat, S., Palsaniya, D., Singh, R., Dhyani, S.K., Kumar, N., Tewari, R. K., Singh, M., Shridhar, K., Newaj, R., Dwivedi, R., Kumar, R., Yadav, R., Chand, L., Kumar, D., Prasad, J., 2020. Bamboo-based agroforestry system ( Dendrocalamus strictus + sesame - chickpea ) for enhancing productivity in semi-arid tropics of Central India. Agrofor. Syst. 8 https://doi.org/10.1007/s10457-020-00492-8.

Enahoro, D., Lannerstad, M., Pfeifer, C., Dominguez-Salas, P., 2018. Contributions of livestock-derived foods to nutrient supply under changing demand in low- and middle-income countries. Glob. Food Sec. 19, 1-10. https://doi.org/10.1016/j. gfs. 2018.08.002.

FAO, 2013. FAO Statistical Yearbook 2013, World food and Agriculture. Food and Agriculture Organization of the United Nations, Rome.

FAO, 2015. FAO Submission to the UNFCCC - Executive Committee of the Warsaw International Mechanism for Loss and Damage under the Work Plan AA7.

Feliciano, D., Ledo, A., Hillier, J., Nayak, D.R., 2018. Which agroforestry options give the greatest soil and above ground carbon benefits in different world regions? Agric. Ecosyst. Environ. 254, 117-129. https://doi.org/10.1016/j.agee.2017.11.032.

Garg, K.K., Karlberg, L., Barron, J., Wani, S.P., Rockstrom, J., 2012. Assessing impacts of agricultural water interventions in the Kothapally watershed, southern India. Hydrol. Process. 26, 387-404. https://doi.org/10.1002/hyp.8138.

Garg, K.K., Anantha, K.H., Nune, R., Akuraju, V.R., Singh, P., Gumma, M.K., Dixit, S., Ragab, R., 2020a. Impact of land use changes and management practices on groundwater resources in Kolar district, Southern India. J. Hydrol. Reg. Stud. 31, 100732.

Garg, K.K., Singh, R., Anantha, K.H., Singh, A.K., Akuraju, V.R., Barron, J., Dev, I., Tewari, R.K., Wani, S.P., Dhyani, S.K., Dixit, S., 2020b. Building climate resilience in degraded agricultural landscapes through water management: a case study of Bundelkhand region, Central India. J. Hydrol. 591, 125592 https://doi.org/ 10.1016/j.jhydrol.2020.125592.

Garg, K.K., Anantha, K., Barron, J., Singh, R., Dev, I., Dixit, S., Whitbread, A., 2021a. Scaling-up of Agriculture Water Management Interventions for Building System Resilience in Bundelkhand Region of Central India. Forthcom. 2021 FAO FAO Agric. Dev. Econ. Tech. Stud.

Garg, K.K., Anantha, K.H., Venkataradha, A., Dixit, S., Singh, R., Ragab, R., 2021b. Impact of rainwater harvesting on hydrological processes in a fragile watershed of South Asia. Groundwater 1-17. https://doi.org/10.1111/gwat.13099.

GOI, 2002. Report of the Working Group on Animal Husbandry and Dairying: Tenth Five Year Plan (2002-2007). Planning Commission, New Delhi.

Gupta, A.K., Nair, S.S., Ghosh, O., Singh, A., Dey, S., 2014. Bundelkhand Drought: Retrospective Analysis and Way Ahead. New Delhi.

Hope, R.A., 2007. Evaluating social impacts of watershed development in India. World Dev. 35, 1436-1449. https://doi.org/10.1016/j.worlddev.2007.04.006.

IGFRI, 2015. IGFRI VISION 2050. Jhansi, U.P, India.

Karlberg, L., Garg, K.K., Barron, J., Wani, S.P., 2015. Impacts of agricultural water interventions on farm income: an example from the Kothapally watershed. India. Agric. Syst. 136, 30-38. https://doi.org/10.1016/j.agsy.2015.02.002.

Kerr, J., 2002. Watershed development, environmental services, and poverty alleviation in India. World Dev. 30, 1387-1400. https://doi.org/10.1016/S0305-750X(02) 00042-6.

Komarek, A.M., Dunston, S., Enahoro, D., Godfray, H.C.J., Herrero, M., MasonD’Croz, D., Rich, K.M., Scarborough, P., Springmann, M., Sulser, T.B., Wiebe, K., Willenbockel, D., 2021. Income, consumer preferences, and the future of livestockderived food demand. Glob. Environ. Chang. 70, 102343 https://doi.org/10.1016/j. gloenvcha.2021.102343.

Kumar, R., Singh, M., 2015. Fodder Production and Preservation. In: Sankhala, G., Balasubramani, N., Meena, H.R., Chakravarty, R., Meena, B.S., Singh, K. (Eds.), All India Animal Husbandry Officers' Workshop Cum Training Program on Enabling Extension Functionaries to Address Field Level Problems in Animal Husbandr. National Dairy Research Institute, ICAR, pp. 70-83. Retrieved May 18, 2017, Karnal, Haryana. 
Mekonnen, A., Tessema, A., Ganewo, Z., Haile, A., 2021. Climate change impacts on household food security and farmers adaptation strategies. J. Agric. Food Res. 6 , 100197 https://doi.org/10.1016/j.jafr.2021.100197.

National Livestock Policy, 2013. Government of India Ministry of Agriculture Department of Animal Husbandry, Dairying \& Fisheries. WWW Document. GOI Gov, India.

Oladosu, Y., Rafii, M.Y., Magaji, U., Abdullah, N., Ramli, A., Hussin, G., 2017. Assessing the representative and discriminative ability of test environments for Rice breeding in Malaysia using GGE Biplot. Int. J. Sci. Technol. Res. 6, 8-16.

Planning Commission, 2011. Report of the Working Group on Animal Husbandry and Dairying for the Twelfth Five Year Plan (2012-17).

R Core Team, 2016. R: A Language and Environment for Statistical Computing.

Ramchandra, K.S., Taneja, V.K., Sampath, K., Angadi, U.B., 2007. Livestock feed resources in different agro-ecosystem of India: availability, requirement and their management. Indian J. Ext. Edu. 26, 258-262.

Ranjhan, S.K., Sen, K.C., Ray, S.N., 1999. Nutritive Value of Indian Cattle Feeds and Feeding of Animals. Indian Council of Agriculture Research, New Delhi., New Delhi.

Rathod, P., Dixit, S., 2020. Dairying in Bundelkhand region of Uttar Pradesh: constraints to realizing the potential. Indian J. Anim. Sci. 90, 3-11.

Reddy, V.K., Mahajan, G.R., Paramesh, V., Singh, N.P., 2017. Socio economic status of livestock farmers of ibrahimpur village, North Goa district a benchmark analysis. Econ. Aff. 62, 335. https://doi.org/10.5958/0976-4666.2017.00017.1.

Rockström, J., 2003. Water for food and nature in drought-prone tropics: vapour shift in rain-fed agriculture. Philos. Trans. R. Soc. B Biol. Sci. 358, 1997-2009. https://doi. org $/ 10.1098 /$ rstb.2003.1400.

RStudio Team, 2014. Studio: Integrated Development for R. RStudio, Inc., Boston, MA (Computer Software v0.98.1074).

Ruggia, A., Dogliotti, S., Aguerre, V., Albicette, M.M., Albin, A., Blumetto, O., 2021. The application of ecologically intensive principles to the systemic redesign of livestock farms on native grasslands : a case of co-innovation in Rocha. Uruguay. Agric. Syst. 191, 103148 https://doi.org/10.1016/j.agsy.2021.103148.

Saran, S., Singh, R.A., Singh, R., Rani, S.I., Singh, K.K., 2000. Feed resources for rearing livestock in the Bundelkhand region of Uttar Pradesh. Indian J. Anim. Sci. 70, 526-529.

SAS Institute, 2016. SAS/STAT 9.2 User's Guide, Second Edition: PROC VARCLUS Statement.
Schlaepfer, D.R., Bradford, J.B., Lauenroth, W.K., Munson, S.M., Tietjen, B., Hall, S.A., Wilson, S.D., Duniway, M.C., Jia, G., Pyke, D.A., Lkhagva, A., Jamiyansharav, K., 2017. Climate change reduces extent of temperate drylands and intensifies drought in deep soils. Nat. Commun. 8, 1-9. https://doi.org/10.1038/ncomms14196.

Sekaran, U., Lai, L., Ussiri, D.A.N., Kumar, S., Clay, S., 2021. Role of integrated croplivestock systems in improving agriculture production and addressing food security a review. J. Agric. Food Res. 5 https://doi.org/10.1016/j.jafr.2021.100190.

Singh, R., Garg, K.K., Wani, S.P., Tewari, R.K., Dhyani, S.K., 2014. Impact of water management interventions on hydrology and ecosystem services in GarhkundarDabar watershed of Bundelkhand region, Central India. J. Hydrol. 509, 132-149. https://doi.org/10.1016/j.jhydrol.2013.11.030.

Singh, C., Solomon, D., Bendapudi, R., Kuchimanchi, B., Iyer, S., Bazaz, A., 2019. What shapes vulnerability and risk management in semi-arid India? Moving towards an agenda of sustainable adaptation. Environ. Dev. 30, 35-50. https://doi.org/ 10.1016/j.envdev.2019.04.007.

Singh, R., Garg, K.K., Anantha, K.H., Akuraju, V., Dev, I., Dixit, S., Dhyani, S.K., 2021 Building resilient agricultural system through groundwater management interventions in degraded landscapes of Bundelkhand region. Central India. J. Hydrol. Reg. Stud. 37, 100929 https://doi.org/10.1016/j.ejrh.2021.100929.

Sreedevi, T.K., Wani, S.P., Sudi, R., Patek, M., Jayesh, T., Singh, S.N., Shah, T., 2006. Onsite and Off-site Impact of Watershed Development : A Case Study of. SAT eJournal, 2, pp. 1-43.

Suthar, B., Bansal, R.K., Gamit, P., 2019. An overview of livestock sector in India. Ind. J. Pure App. Biosci 7, 265-271. https://doi.org/10.18782/2320-7051.7845.

Tanwar, P.S., Verma, H.K., 2017. Feed and fodder availability in Punjab state Vis-à-Vis livestock population -an estimate. Indian J. Anim. Sci. 87, 879-884.

Tyagi, R.K., Shankar, V., 1995. Forage supply-demand analysis for Saurashtra and Kachchh. Range Manag. Agrofor. 16, 45-57.

Varijakshapanicker, P., McKune, S., Miller, L., Hendrickx, S., Balehegn, M., Dahl, G.E., Adesogan, A.T., 2019. Sustainable livestock systems to improve human health, nutrition, and economic status. Anim. Front. 9, 40-49. https://doi.org/10.1093/af/ vfz041.

Wani, S.P., Anantha, K.H., Garg, K.K., 2017. Soil properties, crop yield, and economics under integrated crop management practices in Karnataka. Southern India. World Dev. 93, 43-61. https://doi.org/10.1016/j.worlddev.2016.12.012.

Yan, W., Kang, M.S., 2003. GGE Biplot Analysis: A Graphical Tool for Breeders, Geneticists, and Agronomists. CRC Press, Boca Raton, FL, USA. 